\title{
日本に括ける動物用ホルモン製剤の現況とその応用(つづき)
}

\section{窪 道 護 夫*}

\section{II ホルモン製剤の実際的応用}

\section{III-1 各種動物によるホルモン反応性の相異}

いま, 非妊動物の黄体期に Exogenous Estrogen を負荷し動物の種類による 発情ホルモン 反応性の相異をみると，豚では黄体がきわめて 長期間にわたり持続し，馬も豚と同様の傾向を 示した37)（豚と馬では FSH の分泌を抑制し， LH 分泌を促進すると考台られている）が，牛 では逆に黄体の退化吸收が促進され, 山羊も牛 と同様の所見を呈した（牛と山羊では $\mathrm{FSH}$, LH の分泌を抑制する結果と推測されている). また Estrogen 注射による卵巣沪胞の発育抑制 とその機能回復の状態も動物の種類により著るしく異な り，牛と山羊では卵巣の汇胞の巽常発育（のう腫化）が 誘起されるが，馬，豚ではこのよらなことはなく，正常 の沪胞の発育をもって卵巣機能が開始されると報告され ている37).

一方，筆者の生体内 Estrogen の代謝に联する研究で 32)妊豚尿中に存在する発情ホルモンは 3 種類の Estrogen から成りたっていることが明らかとなり， BREDEK \& MAYER ${ }^{33)}$ のエストラジオールは豚に和いて排泄されて いないといらことは反証された。また妊婦尿中 Estrogen ではェストリオールが主体をなしたが，妊豚ではェスト ロンが主体をなし，妊婦のエストリオール>エストロン >ェストラジオールの順序に対して，妊豚ではエストロ ン>エストラジオール>エストリオールで妊娠時に和け る Estrogen 前軀物質 人と豚とでは異なるのではないかと推察した。

Estrogen 生合成の機序を第 2 図に, Estrogen 転換を

第 2 図 Estrogen の生合成経路

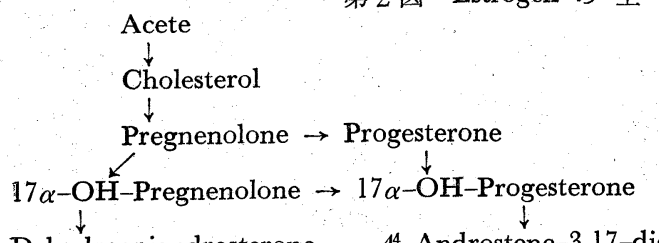

第3図 Estrogen の転 換

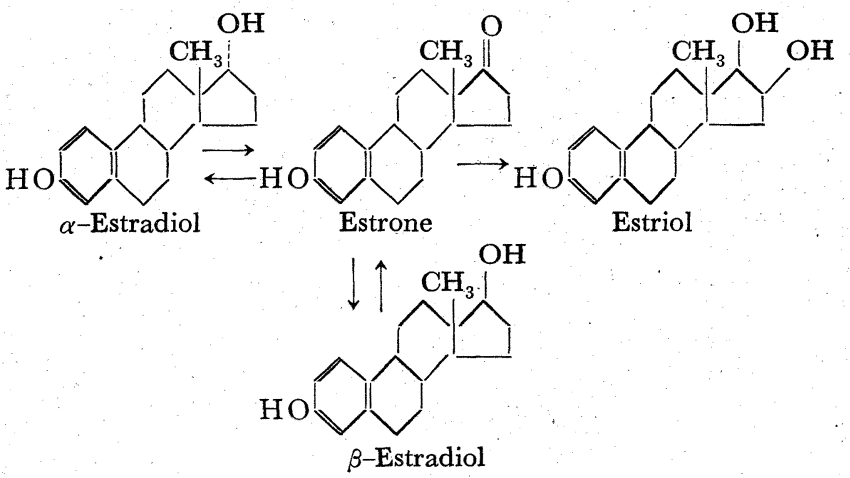

第 3 図に示した。..な妊豚尿中 Estrogen の主体をなす エストロンはほとんど水溶性結合型であった.

ひるがえって，他種動物に打ける尿中排泄 Estrogen の様相をみると，妊馬尿中 Estrogen としてェクイリン

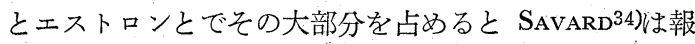
告し, NéLSON \& SMITH ${ }^{35)}$ は妊娠牛 (275日) の尿中Estrogen としてェストラジオール $-17 \alpha, 2.87 \mathrm{mg}$,エストラ ジオール-17, $0.23 \mathrm{mg}$,エストロン, $1.07 \mathrm{mg}$ を分離定量 している. 松本 ${ }^{36)}$ は妊娠家鬼尿中 Estrogen の分離定量 でェストラジオールが最も多くエストリオールは見出せ ないとしている.このように動物の種類による Estrogen 排泄型の様相もまた多様である。

Gonadotropin の動物種によるホルモン反応性の相異 についても Estrogen と同様の傾向が認められている. FSH 作用の強いPMS の微量注射で牛; 山羊の卵巣は 非常によく反応するが，馬，豚では大量の PMSを注射 しても卵巣に沪胞の異常発育を誘起させることができな
Dehydroepiandrosterone $\quad \Delta^{4}$-Androstene-3,17-dione $\rightleftarrows 17 \beta$-Teststerone

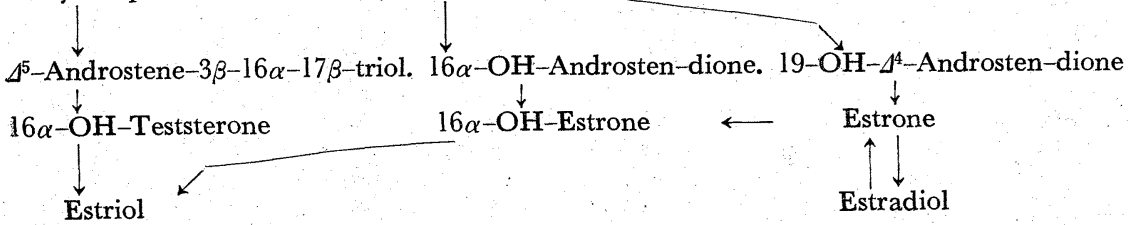

いこと37)など，このよう に動物の種類によるホル モン感受性の著るしく異 なることはホルモン製㓮 の実際的応用上とくに注 意すべき重要なことと思 考される。 また各ホルモ ンの各種動物に対する生 理学的作用も全く同一視 でき得ないことを意味す るものと考えられる. 第 10 表は各種動物の妊娠時

\footnotetext{
* 農林省動物医薬品検査所
} に㧧ける脳下垂体, 卵巣, 胎盤のホルモン分泌の役割り 
第10表 妊娠期に打汸る下垂体，卵巣，胎盤の 役割の比較

\begin{tabular}{|c|c|c|c|c|c|}
\hline & \multicolumn{2}{|c|}{ 妊娠後半期の必要性 } & \multicolumn{3}{|c|}{ 胎盤ホルモンの存在 } \\
\hline & 卵巣 & 下垂体 & $\mathrm{P}$ & 黄体刺激物質 & $\mathrm{E}$ \\
\hline 人 & - & - & \# & $\mathrm{HC} \mathrm{G}$ & \# \\
\hline サ ル & - & - & $H$ & $(\mathrm{HC} \mathrm{G})$ & \# \\
\hline 牛 & $-?$ & & + ? & i & \# \\
\hline メン羊 & - & & + & & + \\
\hline 馬 & - & & H & PMS & \# \\
\hline ウサギ. & + & + & - ? & $+?$ & + \\
\hline ラット & + & - & + & $\mathrm{LTH}$ & + \\
\hline マウス & + & - & + ? & + & + \\
\hline
\end{tabular}

\#：証拠明確. + : 推定. 一：否定.

P : Progesterone. E : Estrogen.

を示した、動物による妊娠時の各種ホルもン分泌機能の 異なることが比較されよう。

\section{II-2 疾病汇対するホルモン製剈の応用}

家畜の繁殖障害の主因である卵巣疾患と子宮疾患に対 するホルモン療法を対象別に列挙するとつぎのように分 類される。

i 卵巣発育障害 脳下垂体前葉の性腺刺激ホルモン の分泌機能低下と考兄られている。 1. 卵巣休止口。 卵巣萎縮 八. 卵巣発育不全

この疾病に対しては Gonadotropin を応用して卵巣機 能を回復せしめ卵胞の発育排卵を起こし，これに伴なっ て発現する発情を期待することが合理的と考兄られてい る.したがってこれに対しては HCG 2,000 MU 1 回注 射，さらに無反応のときは同量を追注することにより良 好な治療効果が得られている38). またPMS 2,000〜3,000 IU で卵胞の発育, 排卵が誘発され有効であるとされて いるが，最近 HCG：PMS 混合製剂が排卵を誘起する のにより効果的であるとされ広く応用されている。

ii 卵巣の弓腫 本病は脳下垂体前葉の FSH の過剩 あるいは分泌機能の六進にもとずくものであるとされて いる.

イ、汇胞のう腫口。黄体のう腫

これに対しては HCG を大量に投与してのら腫を黄体 化せしめ正常卵胞の発育を期待する方法がとられている 38). すなわち HCG 10,000 50,000 MU の注射法が行 なわれている. 本病の治癒機転として大量の HCG 投与 により LH が補われ，病牛に掠ける FSH: LH の Balance が得られ, のう腫変性の軽度の卵胞が黄体化し治 瘺するものであろらとされている. 最近Anti-Hormone に関する成績39)により異なった他の性腺刺激ホルモンた よる治療法が行なわれている.

iii 永久黄体 この疾病は非娃娠にかかわらず卵巣に 黄体が長く存続しその機能を現わすもので，これに対し ては古くから黄体の人工除去法が行なわれているが，そ
の副作用として重度の出血現象が誘発されるのでEstrogen 療法も広く行なわれている。

iv 排卵障害 本病は脳下垂体前葉の性腺刺激ホルモ ソ (LH) の不足により誘発されると考兄られている.

イ.排畉僬延 口. 無排卵

これに対するホルモン治療法として Gonadotropinを 用いて排卵を促進するのが合理的な方法と考えられ $\mathrm{HC}$ G $2,000 \mathrm{MU}$ の投与法が有効として活用されている.

$\mathbf{v}$ 鈍性発情 本疾病は卵胞の成熟, 排卵は周期的に 行なわれているが発情徵候の伴なわないものをいいVENZKE ${ }^{40)} は$ Gonadotropin-Estrogen-Progesterone の不 均衡によると考えている。.またこれに対する治療法とし て Estrogen が広く用いられている。

vi 子宮内膜炎 - 本疾病の病因と性ステロイドホルモ ンは深い相関论あるとされ，化学療法㓮とともに Estrogen の併用療法が行なわれている.

vii 後産停滞 これに対しては抗生物質と之もに Estrogen 脳下垂体後葉ホルモンの併用療法が行なわれてい る.

viii 習慣性早流産 本病の 1 因としてホルモン・ア ンバランスとくに Progesterone の分泌機能低下とも考 えられ, Progesterone ならびに Estrogen の単用または 併用療法が行なわれている。

この注かに妊卵着床障害, 子宮発育不全, 粘 液性子 宮, 腟疾患, 分姢誘導, 陳痛促進, 乳腺症, 黄体期の決 定, 人工発情の誘起，リピード・ブリーダー，菳丸内分 泌機能低下, 芧丸内分泌機能不全など広く繁殖治療に使 用され，またさらに代謝性医薬品としてケトージス，乳 熱, 産後々軀麻瘏, アレルギー性疾患, 気管支喘息, リ ウマチス性関節炎, 皮膚筋炎, 副腎皮質内分泌機能障 害，甲状腺腫，心臟衰弱，心臟拡張，心悸元進，骨多孔 症などその広用範囲は著るしくかつ多伖にわたり利用さ れている.

\section{II-3 ホルモン製剤の生産的応用}

一方，疾病治療を目的としない用途について要約する とつぎのように分類される.

i 早期妊娠診断 家畜の早期妊娠診断法と乙て生物学 的, 化学的, 頭微鏡的, 臨床的, ホルモン学的検查法が ある。しかしてその実施操作が簡単で適中率が高く早期 に診断し得るなどの条件を必要とするが，これらの条件 を十分に満足せしめ得ることは現段階に拈いてはな㧊若 干の困難を有することと考只らている．ホルモン学的 検査法の 1 つとしてエストロダンの発情誘起現象の有無 により判定する早期妊娠診断法41)が応用されている. 本 法は妊娠黄体の存するときは多量のエストロゲンを投与 しても黄体から分泌されるプロゲステロンにより発情現 象を抑制することにもとずくもので，発情黄体による影 響を除去するために交配後16～17日以後に実施すべきで

日獣会誌 18 (1965) 
あるとされている，適中率は乳牛，和牛ともに約 $93 \%$ で ある. 牛では種付後次期発情予定前 $1 \sim 3$ 日目にェスト ロダン 3〜 $5 \mathrm{mg}$ を皮下注射し 24 時間以内の誘起発情 反応陽性を不妊とし，反応陰性を妊娠とする。な扮永久 黄体の場合は反応が現われないから，さらに臨床検査に よる診断に和いて確認する必要がある。馬では交配後14 ～17日後に 2 3 mg を皮下注射し牛に利けると同様の 判定をする.豚においては交配後 17〜20 日に $1 \mathrm{mg}$ を 皮下注射し，74時間以内に判定するが，豚のェストロゲ ンに対する特異性として交配後 2～15日間に注射すると 卵巣黄体は永久黄体化する事実は注目すべきであるとさ れている.

ii 人工泌乳 性ホルモンによる人工泌乳の研究の目 的は泌乳能力の推定ならびに積極的に乳量を増加さすこ とにあるとされている。 またこの研究の 1 面には乳腺の ホルモン生理の解明によって乳腺炎の発生機序をより明 確にし，この炎症の合理的予防治療法を確立することに もある.さてェストロゲンの注射による誘起泌乳曲線の 観察から繁殖期以前に泌乳能力を推定することが可能と なり，今後大いに畜産界に掞いて活用されると思われ る. またこのホルモンの注射による繁殖能力への影響は 現時点においては認められていない。また脳下垂体前葉 ホルモンであるプロラ.クチンは泌乳を保持するに最も重 要であることは STRIKER \& GRÜTER ${ }^{42)}$ の研究以来知ら れている事実であり，脳下垂体後葉ホルモンであるオキ シトシンが乳汁排出現象に重要な Factor であることも よく認められていることである43). この他 ACTH も泌 乳と深い相関にあるとされている.

iii 人工性周期調節 ホルモンの投与により人為的に 性周期を調節する考えは古くから存在していたが，家畜 に実際的に応用されてきたのは比較的新しい．この目的 は脳下垂体一副腎一性腺の各ホルモンの生理的平衡を各 ホルモン製剂の投与によりこれに衝激をあたえ, 発情, 。排卵の同時性 (Synchronization) をはかり, 計画的に多 頭数の人工授精, 妊娠分婏, 計画泌乳などの飼養管理の 省力化, 合理化に積極的に寄与する目的のためホルモン 製剤の応用が進められてきつつある.

iv 肥育発育促進 エストロゲンの単用および甲状腺 機能抑制剤との併用を持続的におこなうと家畜の雌性化 とともに増体促進効果ならびに飼料の利用率の向上をも たらすとされている．とくに合成発情ホルモンであるジ エチルスチルベストロール执よびその誘導体，またメチ ールチオウラシルなどは広く利用されている。

v 人工去勢 幼若動物にェストロゲンを長期間投与 すると (デボ風) ほぼ完全な去勢効果とともに肉質が改 善されるので, この目的のために活用されている.

この他にホルモン製剤の応用されている分野は広沉に わたる，とくに合成非ステロイド系発情ホルモン，甲状
腺機能抑制物質, 性腺ホルモンの単味あるいは複合型で 盛んに活用されている事実は注目すずきであって，これ ら動物用ホルモン製剤の獣医畜産界に占める役割は高く 評価されている.

しかし, ここ数年来, ホルモン治療法の 1 つの動向と して, 蛋白性ホルモン, とくに性腺刺激ホルモンのホル モン拮抗物質について関心が拡われている.これに関し ては,すでに 1931 年, ZONDEK はHCGを雌白鼠に長 期間投与すると卵巣ははじめ肥大充血反応を起こすが， 漸次萎縮して下垂体剔出後と同様の所見を呈することを 観察している. そこでホルモン拮抗物質の活性度が高い 患畜に同種のホルモン剤を投与しても臨床的に治療効果 がないばかりでなく，逆効果をきたすことがあるので， 異なった他の性腺刺激ホルモンの研究, 製剤の開発が行 なわれ実際臨床的に応用されつつある。しかし一般に蛋 白性ホルモンは精製されるに伴ない拮抗物質の生成能が 減少する事実から，家畜においてもなるべく純粋のもの を使用することが当然必要であると思考される．またス テロイドホルモンおよびホルモン物質の過剩投与による Androgenic, Anabolic, Estrogenic および各種作用によ る間脳一下垂体一性腺系ならびに各臓器組織の内分泌, 代謝系に打よぼす影響は重大である．無用のホルモン濫 用はその逆効果により家畜を噔用に陥し入れ甚大な経済 的損失を招来するので㛜につつしまなければならない。 また，これら各種用途で活用されているホルモン製剤の 品質の良非が疾病の治療ならびに生産的応用の成果を支 配するとともにその畜産に抒よぼす影響は重大であるの で各種ホルモンの国家機関による厳重な国家検査が強く 要望されている.

\section{II-4 将来への展望}

さてこれら動物用ホルモン製剩の広範な種類と用途は 内分泌学の進歩と今後ますます増えるであろら家畜飼養 頭羽数との関連からさらに発展してゆくことと思考され る. とくに最近, わが国農業の構造改善について, その 畜産に寄せる期待は大きく統計数字によると現在の家畜 飼盖頭羽数が最近のほ涪 10 年間に牛 (役肉牛, 乳牛) 356 万余頭で毎年 10 15\% の増加率, 豚, 鷄の増加は 飛躍的であり, 生産基礎の整備によるところの農林省の 計画44)によると，昭和 46 年を目標として乳牛 290 万 頭, 肉牛 250 万頭, 豚 740 万頭, 鶏 1 億 2,000 万羽が増 殖目標とされているが，これは需要からみた供給数字で あるけれども，この期間に約 2 倍の生産をしなければ要 求は充たされないと推定されている.この著るしい家畜 飼養頭羽数の急増は当然の帰結として生産性向上に直結 する繁殖ホルモン製郕の漸増を必須とするであろら.

今後，ホルモン製剤が適切に活用されることにより飛 躍的な生産性の向上, 畜産の経済的発展に寄与すると思 考される. 


\section{III 動物用ホルモン製剤の国家検査について}

現在，国産，輸入品を問わず国家機関において検査を 行なっている動物用ホルモン製剤（ジエチルスチルベス トロール，へキセストロール，メチールチオウラシル， 胎盤性々腺刺激ホルモン) について項目別に要点のみを 簡単に記述するが，このほか各種動物用ホルモン製剂を 子含めての特殊基準設定のための準備が進められてい る.

\section{III-1 ジェチルスチルベストロール散剤}

“本品は定量するとき, 表示量の 80.0 ～120.0\% に対応 するジェチルスチルベストロールを含む．

確認試験 本品を表示量にしたがい「ジェチルスチル ベストロール」5 mg に対応する量をとり, ェタノール $30 \mathrm{ml}$ を加光, 振り混ぜたのち, 汇過し, 沪液を蒸発し, 残留物化硫酸 $1 \mathrm{ml}$ を加えて溶かすをき, 液はだいだい 色を呈し, 水 $10 \mathrm{ml}$ を追加するとき退色する.

定量法 本品のジェチルスチルベストロール約 $5 \mathrm{mg}$ に対応する量を精密に測り, 分液 3 斗に入れ, 水 $10 \mathrm{ml}$ および水酸化ナトリウム試液 $20 \mathrm{ml}$ を加兄, 混合, 塩酸 $3 \mathrm{ml}$ を加立酸性とし, エーテル $40 \mathrm{ml}$ づつで 3 回, 30 $\mathrm{ml}$ づつで 2 回抽出する. 全ェーテル抽出液を合わせ, 水酸化ナトリウム試液 $25 \mathrm{ml}$ づつで 3 回, $15 \mathrm{ml}$ で 1 回抽出する. 全水液を合わせ, 希硫酸を加えて酸性と

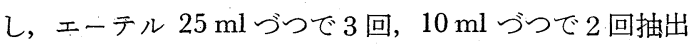
し, 全エーテル抽出液を合わせ沪過する. 少量のエーテ ルで数回洗い，汇液抒よび洗液を合わせ，エーテルを留 去する. 残留物にェタノール $20 \mathrm{ml}$ を加光て溶かし, メ スフラスコに入れ，ェタノール $10 \mathrm{ml}$ づうで 3 回洗い 入れ，水を加光て正確に $100 \mathrm{ml}$ とし試料原液とする. 試料原液 $10 \mathrm{ml}$ を正確に測り希塩酸 $2 \mathrm{ml}$, リンモリブ デン酸タングステン試液 $4 \mathrm{ml}$ 㧊よび水 $50 \mathrm{ml}$ を加え, 10分間放置後, 炭酸ナトリウム溶液 $10 \mathrm{ml}$ 和よび水を 加えて正確に $100 \mathrm{ml}$ とし, 振り混ぜたのち 45 分間放 置し, 乾燥沪紙を用いて沪過し, 汇液 $20 \mathrm{ml}$ を試料溶 液とする. 別にジェチルスチルベストロール標準品約 5 $\mathrm{mg}$ を測り, エタノール $50 \mathrm{ml}$ で溶かし, 水で正確に $100 \mathrm{ml}$ とし標準原液とする.標準原液 $10 \mathrm{ml}$ 㧊よび希 エタノール $10 \mathrm{ml}$ を正確に量り, 各々試料原液と同様に 操作し, 標準液および対照液とする。試料溶液および標 準液につき，対照液を用いて層長 $10 \mathrm{~mm}$, 波長 $780 \mathrm{~m} \mu$ で試料溶液, 標準液の吸光度 ET および ES を測る。 ジェチルスチルベストロールの量

$$
(\mathrm{mg})=\text { 標準品の量 }(\mathrm{mg}) \times \frac{\mathrm{ET}}{\mathrm{E} \mathrm{S}}
$$

III-2 ヘキセストロール散剤

本品は定量するとき，表示量の 80.0 ～120.0\%に対応 するへキセストロールを含む.

確認試験 本品の表示量にしたがいへキセストロール 日獣会誌 18 (1965)
$0.25 \mathrm{~g}$ に対応する量をとり，エーテル $20 \mathrm{ml}$ を加光沪 過し, '蒸発, 残留物を水浴上で乾固する. これに無水眽 酸 $1 \mathrm{ml}$ 㧊よび無水ピリジン $2 \mathrm{ml}$ を加兄, 還流冷却下, 15分間煮沸したのち, 水 $50 \mathrm{ml}$ を加克, 激しく振盪, 1 時間放置する. 沈殿を沪取し, 水で洗い, $75 \sim 80^{\circ} \mathrm{C} て ゙$ 18時間乾燥するとき，その融点は $136 \sim 139^{\circ} \mathrm{C}$ である.

定量法 本品のへキセストロール約 $5 \mathrm{mg}$ に対応する 量を量り分液沪斗に入れ, 以下「ジェチルスチルベスト ロール散剤」の定量法を準用する。ただし標準品はへキ セストロールを用いる.

\section{III-3 メチルチオウラシル散剤}

本品は定量するとき, 表示量の 83.0 1 117.0\%に対応 するメチルチオウウラシルを含む.

確認試験 本品を表示量にしたがいメチルチオウラシ ル $0.2 \mathrm{~g}$ 亿対応する量をとり, アンモニア試液 $5 \mathrm{ml}$ を加 え, ときどき振り混ぜ 5 分間放置したのち, 水 $10 \mathrm{ml}$ を 加えて沪過する. 汇夜を加熱し, 水で洗い $105^{\circ} \mathrm{C}$ で恒量 になるまで乾燥するときその融点は約 $330^{\circ}$ である.

定量法 本品を表示量にしたがいメチルチオウラシル 約 $0.3 \mathrm{~g}$ に対応する量を精密に量り, 水 $30 \mathrm{ml}$ を加党, $0.1 \mathrm{~N}$ 水酸化ナトリウム液 $30 \mathrm{ml}$ を加え, 沸騰するまで 加熱し溶解する。 $0.1 \mathrm{~N}$ 硝酸銀液 $50 \mathrm{ml}$ を加穴, 5 分間

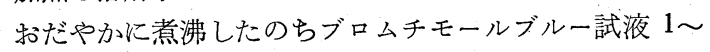
$2 \mathrm{ml}$ を加え $0.1 \mathrm{~N}$ 水酸化ナトリウム液で持続する青緑 色を呈するまで滴定をつづけ前後の消費量を合わせる.

$0.1 \mathrm{~N}$ 水酸化ナトリウム液 $1 \mathrm{ml}=8.512 \mathrm{mg}$ メチルチオ ウラシル.

\section{III-4 動物用胎盤性々腺刺激ホルモン}

このホルモンは動物用胎盤性々腺刺激ホルモン検査基 準案 ${ }^{45)}$ にむとずいて国家検査を行なっている.この基準 案は妊婦尿, または胎艋から得た性腺刺激ホルモンの純 末，または適当な希积剂で希釈したものについてであっ てその大要はつぎのごとくである.

$\mathrm{i}$ 検査は特性試験, 無菌試験および力価試験につい て行なう.

ii 製剂はつぎの基準に適合していなければならな w.

イ. 特性試験の結果, 製剂固有の色, その他の物理的 性状を有し, 各小分容器内の内容の性状が均一であるこ と.

口。無菌試験の結果, 検出できるいかなる生菌をる存 在していないこと.

八. 力価試験の結果, 胎盤性々腺刺激ホルモンの表示 力価を十分に含有するものであること．

iii 前記イから八までの試験において，その結果を判 定するのに困難が生じたときは当該試験を反復する.

付記

i. 特性試験実施上の注意: 溶解状態を検查する場合 
第11表 動物用 HC G 製剤の移植

\begin{tabular}{|c|c|c|c|c|c|}
\hline $\begin{array}{l}\text { 小分容 } \\
\text { 器の種 } \\
\text { 類 }\end{array}$ & $\begin{array}{l}\text { 移 } \\
\text { 植 } \\
\text { 量 }\end{array}$ & $\begin{array}{l}\text { 培 } \\
\text { 地 } \\
\text { 数 }\end{array}$ & $\begin{array}{l}\text { 移植量 } \\
\text { 培地 } \\
\text { 本数 }\end{array}$ & & 備 \\
\hline cc & cc & 本 & & \multirow{3}{*}{\multicolumn{2}{|c|}{ 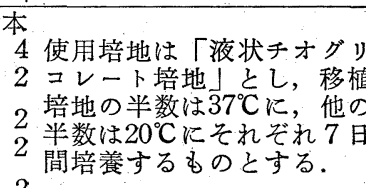 }} \\
\hline 50 & 5 & 6 & $\left\{\begin{array}{l}1 \\
0.5\end{array}\right.$ & & \\
\hline 25 & 3 & 4 & $\left\{\begin{array}{l}1 \\
0.5\end{array}\right.$ & & \\
\hline 20 & 3 & 4 & $\left\{\begin{array}{l}1 \\
0.5\end{array}\right.$ & & \\
\hline 10 & 2 & 4 & 0.5 & 4 & \\
\hline 5 & 2 & 4 & 0.5 & 4 & \\
\hline 2 & 2 & 2 & 0.5 & 2 & . \\
\hline
\end{tabular}

には試験品の小分容量ごとに, 規定量の滅菌生理食塩液 を容器の縁にそって静かに注加し, 軽く振とうして容易 に溶解するか否か，およびその状況を観察すること．

口. 無菌試験実施上の注意: 動物用生物学的製剂検査 一般基準付記 I によること．ただし材料の移植量および 移植本数はつぎによること.

口-1 製剂の移植は第 11 表により行ならこと．ただ し, 試験すべき製剤の小分容器の種類闌に揭げる区分に 相当しないときは, 直近上位の小分容器の区分に従って 移植するものとする.

\section{八. 力価試験実施上の注意}

-1 試験動物は試験前 $2 \sim 4$ 日健康観察を行ない環 境に順応したものであること. 体重は 7.5 8.5 g の幼 若雌マウスであって 1 群 15 匹づつ 2 群 30 匹を使用す る.これらの群をそれぞれ 0.5 単位群和よび 2 単位群に 区別して試験を実施する.

八-2 検体の調製拉よび保管：被検品はそれぞれ表示 力価を基とし, 生理食塩液をもって溶解または希釈して $0.4 \mathrm{cc}$ 中に 0.5 単位および 2.0 単位を含有する各々 2 種 の溶液を調製し $0 \sim 5^{\circ} \mathrm{C}$ に保管する。

-3 試験方法 : 試験は上記濃度の調製液ごとにそれ ぞれの群のマウス 1 匹につき $0.1 \mathrm{cc}$ づつを朝夕 2 回 2 日間（計 4 回，1匹 $0.4 \mathrm{cc}$ ) それぞれマウスの皮下に注 射し, 第 1 回注射後 100 時間目に剖見を行なって, 卵巣 に認められる出血点および黄体の有無を検査する.

八-4 被検品注射群と同一の条件のもと飼育された 同数のマウス群に既知の力価を有する胎盤性々腺刺激木 ルモンの同単位を注射し同時間後に解剖を行なって，そ の反応を確認する.

二. 判定 : 判定は剖見所見に括いて卵巣に出血点また は黄体を認めたものを陽性とし各群ごとに試験マウスに 対する陽性マウスの百分率を算出し，0.5 単位群では50 \%以下， 2 単位群では $70 \%$ 以上の陽性率を認めたとき 合格とする．ただしつぎの各項に該当したマウスは判定 から除外すること.
ニ-1 剖検時に和汗る体重が注射開始時より減少した 場合.

二-2 剖見時に抢ける体重が注射開始時より $4.5 \mathrm{~g}$ 以 上増加した場合.

$=-3$ 外観上明らが異常が認められた場合.

ホ. 再検査：つぎの場合は再検租を行なら.

ホ-1 試験マ.ウスが10匹に満たない群を生じた場合.

ホ-2 2 単位群に执いて陽性率が $70 \%$ 未満であって も $50 \%$ 以上の場合.

ホー3 0.5 単位群において陽性率が $50 \%$ を越しても $60 \%$ 以下の場合.

ホー4 その他，結果を判定するのに困難を生じた場 合.

なお，マウス単位の基準は 7.5 8.5 g の幼若雌マウ スに検体を注射し，使用動物の $60 \%$ に陽性反応を呈せ しめるに要する量を1 マウス単位 (IMU) とされている. 反応の判定は発情期胵垢像の出現および出血点あるいは 黄体発生の卵巣変化のうち少なくともいずれか 1 反応を 認めたものを陽性とする.このマウス単位と国際単位 (IU) との関係は打上去 $\mathrm{IMU}=3 \mathrm{IU}$ と考学られてい る.

以上, HCG のマウス単位による検査法を記したが， このホルモンは 1938 年, 第 3 回ホルモン物質標準設定 国際会議沈いて国際標準品 (International Standard Preparetion）が設定されており，その $100 \mu \mathrm{g}$ の効力を 1 国際単位 (International Unit) と決められていて, London の National Institute for Medical Research ら各国へ提供されることになっている。したがって動物 用 $\mathrm{HCG}$ 製剤の力価も万国共通の国際単位で表示する検 査方法を研究することは将来のため重要であると思考さ れる.

また最近約 10 年の間に HCG, PMS, APG の生物 学的特異活性に基づく FSH, LH の分離定量法 (STEELMAN, PoHLEY46)の Augmentation Method とょるFSHの 検定, PARLOW, REICHERT47) の卵巣アスコルビン酸減少 法によるLHの検定)が開拓されるとともに, 免疫化学的 方法で蛋白性ホルモンを定量しょうとする試みもなされ (YALOW，BERSON48)によるインシュリンの電気泳動によ る Immunoassay, WIDE, GeMZelL 49) とょる尿中 HCG の赤血球凝集抑制反応, その他50) これら諸法による研究 は現在内分泌の分野で活発に展開されている.今後これ ら諸法の発展により，より簡易に，そして精度，感度な どすべての点ですぐれた測定法が生まれ出て生体内ホル モン作用の機序の解析に，また各種ホルモン製剤の力価 の検定に役立つことであるうことを期待する.

\section{あこがき}

日本に和ける動物用ホルもン製剂についてその一般的 概要を簡単に記述したが，畜産界に和けるこの分野は今 
後ますます発展するであろうことが思考されるだけに， より一層の研究とたゆま努力がなされることを新るも のである.

擱筆にあたり川島秀雄所長, 恩師須藤恒二博士に深謝 する。

$$
\text { 文 献 }
$$

1) 森島庫太: 薬理学, 南江堂, 東京 (1957). 2) C.W. Emmens: Hormone Assay Academic Press New York (1950). 3) P.E. Sмiтh: Anat Record 32. 221 (1926). 4) B.Zondex \& S. AschHeim : Klin Wochschr. 6. 248 (1927). 5) S. AschHerm \& B.Zondek: Klin Wochschr. 6. 1332 (1927). 6) H. H.Cole \& G. H. HaRT: Am. J. physiol. 93. 57 (1930). 7) H.H. Cole \& H. Gross: Essay in Biol, University California Press 107 (1943). 8) C. H. Li, M. E. Simpson, H. M. Evans: Science 109. 446 (1949). 9) C. H. Li, M. E. Simpson, H. M. Evans : Endocrinol. 27. 803 (1940). 10) C.H.Li, W.R. Lyons, H. M. Evans : J. Am. Chem. Soc., 62.2925 (1940).

11). Ellis, S : J. Biol. Chem., 233. 63 (1958). 12) Squire. P. G. \& Li. C. H : J. Biol. Chem., 234. 520 (1959). 13) Sluyser, M. \& Li. C. H. : Arch Biochem. Biophys. 104. 50 (1964). 14) Murata, M \& AdACHI. K : Z. Geburtschülfe U Gynäkol, 92, 45 (1928). 15) S. AschHeim : Vortr. Berliner Gynäkol Gesellschaft, 12. 14 (1928). 16) Hamburger. C : Ugeskrift Laeger. 93. 27 (1931). 17) Li. C. H \& Pederson, K. O. : J. Gen. Physiol. 35. 629 (1952). 18) Steelman, S. L., SegaLoff, A: Recent. Progr. Hormon. Res. 15. 115 (1959).

19) Squire, P.G. \& Li. C. H : Science 127. 32 (1958). 20) Li. C. H., SQuire, P.G., Groschel, U: Arch. Biochem. Biophys. 86.110 (1960).

21) S. AschHeIm \& B. ZoNDEK : Klin Wochschr, 6. 1322 (1927). 22) Doisy, E.A., Veler, C.D., ThayER, S.A.: Am. J. Physiol. 90. 329 (1929). 23) BuTENANDT, A: Naturwissenschaften, 17. 878 (1929). 24) Girard, A., Sandulesco, G., Fridenson, A., Rutgers, J.J.: Compt. Rend. 194. 909 (1932). 25) Wintersteiner, O. Schwenk, E, Whitman, B : Proc, Soc. Exptl, Biol, Med, 32, 1087 (1935). 26) Maccorquodale, D. W., Thayer, S.A., Doisy, E.A. : J. Biol. Chem, 115. 435 (1936). 27) Kendall, E.C.,: J. Biol. Chem. 20. 501 (1915), 28) Gross, J. \& R, Pitt-Rivers: Biochem. J. 53, 645 (1953). 29) Stanbury, J. B.: Ann. New york Acad Sci, 86, 417 (1960). 30) LeHNINGER, A.L: Ann, New york, Acad, Sci, 86, 487 (1960).

31) KENNEDy, Astwood : 第 2 改正国民医薬品集註 解, 南江堂, 東京, 224 より引用 (1959). 32) 洼道護 夫：農林省家畜衛生試験場，水矅会記事，13.1 (1964). 33) BREDECK, H,E \& MAYER, D.T. : Reproduction \& Infertility III Symposium, (F.X. GASSNER) Pergamon, London, $157^{\circ}$ (1958). 34) SAVARD, K.: Endocrinol. 68, 411 (1961). 35) D.W.Nelson \& E.P. Smith: J. Dairy, $S c i, 46.135$ (1963). 36) 松本圭央 : 内分泌之代謝 1. 227 (1958). 37) 西川義正：農業技術研究所報告, G14,3 (1958). 38) 山内 亮 : 家畜繁殖学, 最近のあ

日獣会誌 18 (1965)
ゆみ，家畜繁殖研究会編， 242 (1957)，39）中原達夫 : 日獣会誌, 17. 509 (1964). 40) VenzKe, W.G .: J. Am. Vet. Med. ASS, 115, 347 (1949).

41）西川義正：農業技術研究所報告, G-10.147 (1955). 42) Stricker, P \& Grüter, F.: Comptes. Red. Soc. Biol, 99. 1978 (1928). 43) Cross, B.A. \& Harris, G.W : J. Endocrinol. 8. 148 (1952). 44) 大川忠男 : 日獣会 誌， 17. 555 (1964). 45) 農林省：動物用生物学的慗 剤検定特殊基準 (1962). 46) Steelman, S.L., Pohley, F.M: Endocrinol. 53. 604 (1953). 47) Parlow, A.F., ReICHERY, L.E.Jr: Endocrinol. 73.337 (1963). 48) Berson, S.A., \& YAlow, R.S.: J. Clin. Invest, 39. 1157 (1960). 49) Wide, L. \& Gemzell, C.A: Acta Endocrinol. 35. 261 (1960). 50) BRODY, S. \& CARLSTRöM, G: Lancet. 9.99 (1960).

\section{小動物臨床に和ける臨床細菌学的検索}

化膿創では病原菌を分離し，それが感受性を有する抗 生物質を決定することにより，はじめて有効から合理的 な治療が可能である. 以下はミシガン州立大学が犬につ いて行なった検索の結果である.

犬の皮膚炎 117 例のらち 64 例から黄色ブドウ球菌が 単独で分離された。残る 53 例 51 例はいずれもブドウ 球菌と他の菌が混合感染したものであったが，その中で は溶血性連鎖球菌との組合せが34例とずばぬけていた。 したがって 117 例中 115 例にブドウ球菌が認められたこ とになる. また犬の結膜炎および角膜炎 66 例のうち， 黄色ブドウ球菌が 42 例 (単独 20 例, 混合 22 例) に, 溶血性連鎖球菌が 26 例に，むた緑膿菌が 6 例にそれぞ れ認められた. 犬の骨髄炎 18 例では混合感染例が多か ったが，黄色ブドウ球菌は最も多く，15例で検出され， 溶血性連鎖球菌 10 例，緑膿菌 5 例であった.

このようにして分離された主なる菌の 11 種類の抗生 物質に対する感受性試験の結果をみると, 黄色ブドウ球 菌 101 例のうち, polymyxin B (P.B.) に対しては全例, dihydrostreptomycin (SM) に対しては 1/4, chlortetracycline (CT), oxytetracycline (OT), fetracycline (T) に 対しては 1/3, penicillin (P) に対しては 1/2 がそれぞれ 耐性を有していた：注とんど全例に有効であったのは bacitracin (B), carbomycin (CM), chloramphenicol(C), erythromycin (E) および neomycin (N) であった. 溶 血性連鎖球菌 45 例の大部分は PB および $\mathrm{N}$ に対し耐 性を有し, 半数が S.M. に酎性であったが， B, CM, C, $\mathrm{E}, \mathrm{OT}, \mathrm{P}, \mathrm{T}$ はほとんど全例で有効であった. 変形菌 16例は酎性菌が多く, C, SM, N にのみ感受性を有して いた. 緑膿菌に対しては有効な薬が少なく，12例中 7 例 がSM および PB に対して感受性を示したのが最高であ った. B， CM, E，P は全例で無効であった.

(J.P. Newman; M.S.U. Vet., 25, 5, 1965) 